\title{
Nedestruktivní archeologie př̀i výzkumu hrobek v Čechách
}

\author{
Vladimír Hašek ${ }^{1}$ - Jiř́ Šindelář ${ }^{2}$ - Josef Unger ${ }^{3}$ \\ ${ }^{1}$ Isolines, spol. s r.o., Došlíkova 3, 63600 Brno \\ ${ }^{2}$ Naše historie o. s., Měšická 1724, 39002 Tábor \\ ${ }^{3}$ Ústav antropologie Př́rodovědecké fakulty Masarykovy univerzity, Vinařská 5, 60300 Brno
}

Do redakce doručeno 14. března 2013; k publikaci přijato 21. srpna 2013

\section{NON-DESTRUCTIVE ARCHAEOLOGY IN SURVEY OF TOMBS IN BOHEMIA}

ABSTRACT The article deals with the use of non-destructive geophysical methods at the exploration of tombs in the interiors of medieval and early modern religious buildings. The method of soil radar, eventually mikrogravimetrie with subsequent inspection and documentation by camera system appears to be optimal for the localization of tombs, graves and other structures in the interiors of churches. This was found from practical examples prospecting at localities Prague-Hradčany, Vyšší Brod and Želiv. The use of these methods is dependent on the character of the inhomogeneities. It means if it is lined walls object, or just simple grave (unfulfilled, peppered and similarly). Reflections of electromagnetic waves are the most significant and survey of camera gives good results if the tomb is walled, hollow and it has a larger dimension. Smothering of object can lead to ambiguous interpretation and survey of camera is impossible. Then you need to apply additional information regarding of networks engineering, older masonry etc. The localization of filled objects is often very problematic and undetectable when there exists a similar backfill of soil.

KEY WORDS archaeology; geophysics; graves; burials; medieval period; modern period

ABSTRAKT Komplex nedestruktivních metod se v Čechách stal v průběhu posledních několika let i přes určité komplikace v jejich zavádění do praxe, již nedílnou součástí komplexně pojatého archeologického výzkumu i stavebně-historického průzkumu při řešení různých otázek spojených zejména s lokalizací hrobek, hrobů, krypt a reliktů zdiva ze starších snesených objektů v interiérech středověkých i novověkých církevních staveb. Ve spojení geofyzikálních metod s vizuálním průzkumem a dokumentací, př́padně sondáží zabezpečuje tento postup optimální řešení požadovaných úloh a to jak z hlediska získání velkého počtu informací, tak z hlediska časového a v neposlední řadě i ekonomického.

Z uváděných praktických příkladů výsledků dosavadní prospekce na lokalitách Praha-Hradčany, Vyšší Brod a Želiv se jeví jako optimální pro lokalizaci hrobek, hrobů a dalších struktur v interiérech kostelů metoda půdního radaru, př́padně i mikrogravimetrie s následnou prohlídkou a dokumentací kamerovým systémem. Optimální případ nastává tehdy, když je hrobka vyzděná, dutá a má větší rozměr. $V$ tom př́ípadě jsou odrazy elektromagnetických vln nejvýraznější, respektive dochází k úbytku hmot a tento objekt je pak velice dobře detekovatelný. Př́i jeho zavalení může při výkladu docházet $\mathrm{k}$ nejednoznačné interpretaci, kdy jej lze přiřadit k větším plošným kumulacím kamenů, litologickým změnám v zásypu antropogenní vrstvy, nebo reliktům zdiva ze starší snesené stavby. Zde jsou potom velmi užitečné další doplňující informace o stavbě, jako např́klad př́ípadné polohy náhrobních kamenů, umístění těchto prvků v sakrální stavbě, průběhy inženýrských sítí apod. Při existenci zásypu prostých hrobů obdobného litologického složení, respektive zhutnění jako v okolním prostředí je jejich interpretace vlivem nevýrazných změn fyzikálních parametrů zemin velmi problematická a mnohdy lokalizace i nezjistitelná.

KLÍČOVÁ SLOVA archeologie; geofyzika; hroby; pohřby; středověk; novověk

\section{ÚVOD}

Křestanská sakrální architektura Čech představuje $\mathrm{v}$ rámci studia dějin hmotné kultury relativně širokou oblast památek.
Jedná se zejména o rozsáhlé spektrum různých typů kostelů, kaplí, klášterních komplexů a menších kultovních útvarů z období od 9. století až do současnosti. Archeologický i stavebněhistorický výzkum těchto objektů, situovaných do are- 


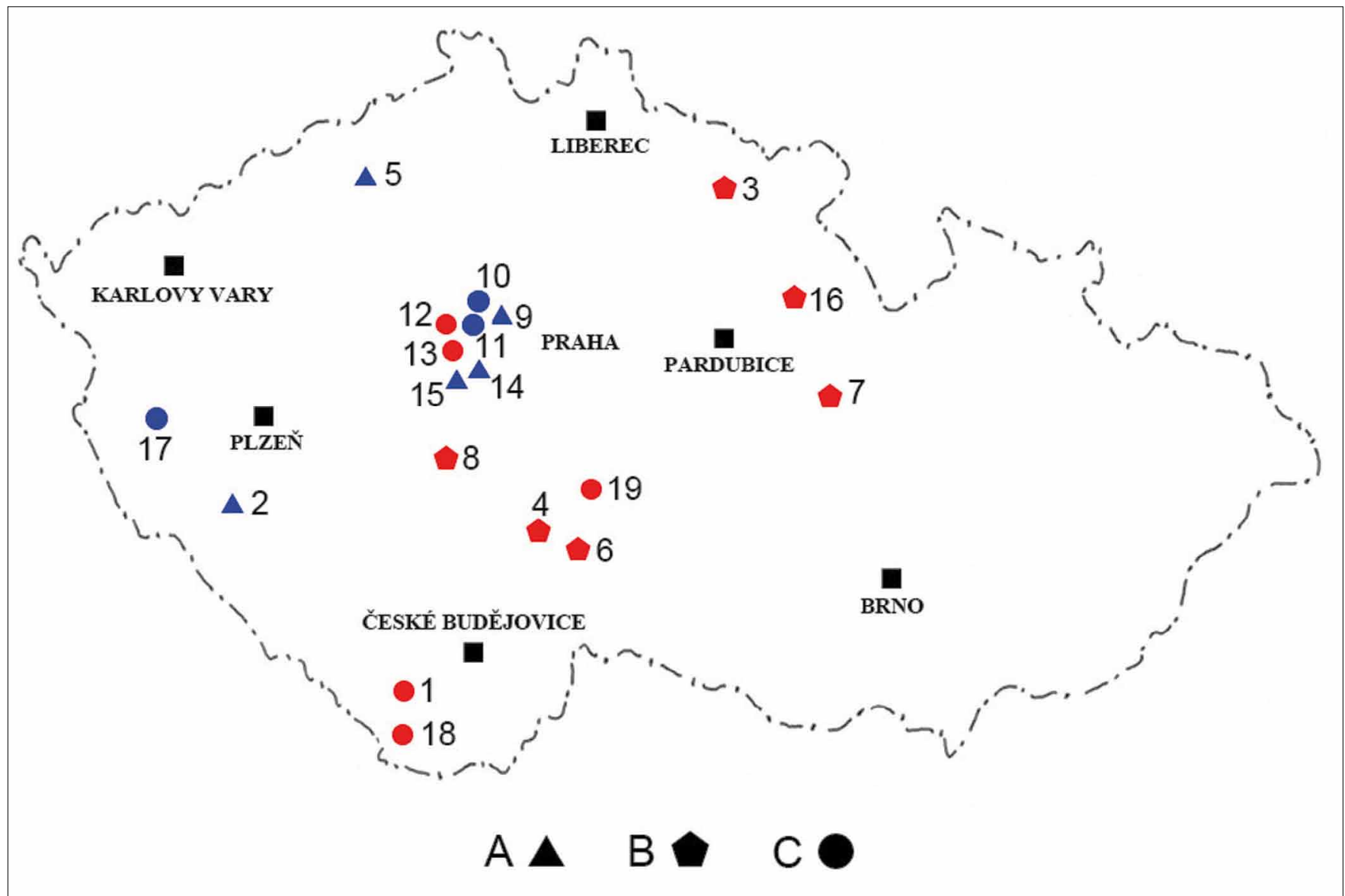

Obr. 1. Církevní stavby Čech prozkoumané geofyzikální prospekcí v různých etapách těchto prací a realizovaný výzkum. A - pokusná testovací a výzkumná měření; B - systematická prospekce; $\mathrm{C}$ - archeologický výzkum (i částečný - sondáž). Průzkum institucí z Čech je značen modrou barvou a institucí z Moravy červenou barvou. 1 - Český Krumlov; 2 - Dolany; 3 - Hostinné; 4 - Chýnov; 5 - Kostomlaty pod Milešovkou; 6 - Křeč; 7 - Litomyšl; 8 - Obděnice; 9 - Praha-Hostivař; 10 - Praha-Hradčany; 11 - Praha-Staré Město (sv. Haštal); 12 - Praha-Staré Město (Křižovatka); 13 - Praha 2-Spálená ulice; 14 - Praha-Staré Město; 15 - Praha-Vyšehrad; 16 - Přepychy; 17 - Svojšín; 18 - Vyšší Brod, 19 - Želiv.

álů městských aglomerací i vesnického prostředí, se zabývá stanovením jejich celkové půdorysné situace spolu s určením polohy př́ipadné starší zaniklé stavby a v neposlední řadě pak i některými otázkami spojenými se zjištováním statického narušení způsobeného geologickými poměry v okolí předmětného díla a mechanickým chováním základových půd, tak úrovní hladiny podzemní vody nebo zvlhčením zdiva (Hašek - Měřínský 1997, 425; Hašek - Unger 2010, 1). V současné době důležité místo při archeologickém bádání v českém prostředí je řešení lokalizace a dokumentace hrobek a prostých hrobů v interiérech jednotlivých staveb z hlediska sledování pohřebního ritu (Hašek - Unger 2001, 87). Nelze přitom pominout úlohu zjištování př́padných reliktů základového zdiva ze starších snesených objektů v místech pozdějších fází výstavby nebo přestavby chrámů. K úspěšnému vyřešení tohoto úkolu se kromě vlastních odkryvných archeologických prací začínají využívat i nedestruktivní geofyzikální metody. Předpokládaný komplex obou těchto metod může do značné míry nahradit ekonomicky a provozně nákladné destrukční postupy s cílem jejich omezení do míst vytypovaných prospekcí. Předložený příspěvek se zabývá jak nástinem metodického vývoje prací při lokalizaci různých struktur v interiérech sakrálních staveb, tak především některými praktickými výsledky a zkušenostmi z moderního uplatnění nedestruktivních geofyzikálních metod $\mathrm{v}$ kombinaci s kamerovým systémem při řešení uvedené problematiky.

\section{P̌̌EHLED UPLATNĚNÍ KOMPLEXU GEOFYZIKÁL- NÍCH METOD PŘI PRŮZKUMU V INTERIÉRECH SAKRÁLNÍCH STAVEB}

První ověřovací geofyzikální měření pro cíle archeologického výzkumu a statického zajištění církevní stavby v Čechách se uskutečnila v Praze-Spálené ulici, v kostele Nejsvětější Trojice, založeném roku 1712, Geofyzika n. p. Brno v roce 1979 (Bednář - Novotný - Švancara 1980, 23) a 1980 (Domanský 1983, 129). Mikrogravimetrickým a geotermickým měřením byla v západní a střední části objektu zjištěna výrazná uzavřená tíhová anomálie a změny v teplotních gradientech. Následný výzkum odkryl rozsáhlou kryptu v blízkosti povrchu pod podlahou. Mezi další akce, které můžeme také zahrnout 


\begin{tabular}{|c|c|c|c|c|c|c|}
\hline lokalita & okres & kostel & $\begin{array}{c}\text { založeno } \\
\text { (stář́ })\end{array}$ & $\begin{array}{c}\text { průzkum } \\
\text { (rok) }\end{array}$ & $\begin{array}{c}\text { geofyz. } \\
\text { indikace }\end{array}$ & poznámka \\
\hline Dolany & Klatovy & sv. Petra a Pavla & $1797-1799$ & 2005 & zdivo & Křivánek 2006, 9 \\
Kostomlaty pod Milešovkou & Litoměřice & sv. Vavřince & románský & 2007 & zdivo & Křrivánek 2008, 15 \\
Praha-Hostivař & - & Stětí sv. Jana Křtitele & románský? & 2008 & krypta & Křivánek 2009, 19 \\
Praha 1-Staré Město & - & dominikánský klášter & 1232 & 2009 & krypta & Křrivánek 2010, 18 \\
\hline
\end{tabular}

Tab. 1. Církevní stavby prozkoumané geofyzikálními metodami v I. etapě těchto prací.

do charakteru experimentálních prací, patří geotermické a geoelektrické odporové měření v areálu baziliky sv. Petra a Pavla v Praze na Vyšehradě, složitého objektu se sedmi stavebními fázemi (románská až novogotická 1070-1903), realizované Archeologickým ústavem ČSAV Praha a Ústavem geologie a geotechniky ČSAV Praha v roce 1981-82 (Hrdlička - Nechvátal 1983, 123-124). V letech 1999-2010 bylo na území Čech prozkoumáno již převážně systematickou geofyzikální prospekcí více než 16 stř̌edověkých, eventuálně novověkých městských i vesnických sakrálních staveb (obr. 1), které můžeme $\mathrm{z}$ hlediska použitých metod a získaných výsledků rozdělit do několika kategorií.
Do první skupiny zahrnujeme testovací měření s výzkumným záměrem, uskutečněné v letech 2005-2009 Archeologickým ústavem AVČR Praha.

Dipólovým elektromagnetickým profilováním a geotermickým měřením byly zde pokusně sledovány relikty základového zdiva ze zaniklých staveb, př́ípadně ověřovány polohy hrobek. $\mathrm{V}$ důsledku existence velkých rušivých recentních vlivů $\mathrm{v}$ prostrou všech zkoumaných objektů byly dosaženy pouze částečně pozitivní výsledky $\mathrm{z}$ těchto průzkumů.

Do druhého, většího okruhu, náleží prospekce, prováděná převážně metodou půdního radaru (GPR), obsahující prozatím pouze geofyzikální interpretaci bez vlastního archeologic-

\begin{tabular}{|c|c|c|c|c|c|c|}
\hline lokalita & okres & kostel & $\begin{array}{l}\text { založeno } \\
\text { (stáří) }\end{array}$ & $\begin{array}{l}\text { průzkum } \\
\text { (rok) }\end{array}$ & $\begin{array}{l}\text { geofyzikální } \\
\text { indikace }\end{array}$ & poznámka \\
\hline Přepychy & $\begin{array}{l}\text { Rychnov nad } \\
\text { Kněžnou }\end{array}$ & $\begin{array}{c}\text { sv. Prokopa } \\
\text { V }\end{array}$ & 1506 & $1999-2000$ & chodba & $\begin{array}{l}\text { Hašek - Petera } \\
\text { 2002, 317; } \\
\text { Hašek - Unger } \\
2010,24\end{array}$ \\
\hline Svojšín & Tachov & $\begin{array}{c}\text { sv. Petra a Pavla } \\
\text { M }\end{array}$ & 17. stol. & 2004 & hrobka & Čechura 2005, 3 \\
\hline Křeč & Pelhřimov & $\begin{array}{c}\text { sv. Jakuba Většího } \\
\text { V }\end{array}$ & 13. stol. & 2006 & hrobka, zdivo & $\begin{array}{c}\text { Hašek - Tomešek } \\
2006\end{array}$ \\
\hline Hostinné & Trutnov & $\begin{array}{c}\text { Nejsvětější Trojice } \\
\text { M }\end{array}$ & raně gotický & 2006 & hrobka, zdivo & $\begin{array}{c}\text { Hašek - Tomešek } \\
\text { 2006a }\end{array}$ \\
\hline Chýnov & Tábor & $\begin{array}{c}\text { Nejsvětější Trojice } \\
\text { M }\end{array}$ & 2. pol. 14. stol. & 2007 & hrobka, zdivo & $\begin{array}{c}\text { Hašek - Tomešek } \\
2007\end{array}$ \\
\hline Český Krumlov & Český Krumlov & $\begin{array}{c}\text { sv. Víta } \\
\text { M }\end{array}$ & 1329 & 2007 & hrobky & $\begin{array}{l}\text { Hašek - Šindelář - } \\
\text { Thomová - Tome- } \\
\text { šek } 2008\end{array}$ \\
\hline Litomyšl & Svitavy & $\begin{array}{c}\text { piaristická kolej } \\
\text { V }\end{array}$ & $1641-1680$ & 2008 & hrobka, zdivo & $\begin{array}{l}\text { Hašek - Unger } \\
\text { 2010, } 33\end{array}$ \\
\hline Obděnice & Příbram & $\begin{array}{c}\text { Nanebevzetí P. Ma- } \\
\text { rie - V }\end{array}$ & 2. pol. 12. stol. & 2008 & hrobka & $\begin{array}{c}\text { Hašek - Tomešek } \\
2008\end{array}$ \\
\hline $\begin{array}{c}\text { Praha - } \\
\text { Staré Město }\end{array}$ & - & $\begin{array}{l}\text { sv. Anny } \\
\text { K }\end{array}$ & 14. stol. & 2010 & hrobka & $\begin{array}{c}\text { Hašek - Šindelář } \\
\text { - Tomešek, dosud } \\
\text { nepublik. }\end{array}$ \\
\hline
\end{tabular}

Tab. 2. Církevní stavby prozkoumané geofyzikálními metodami v II. etapě těchto prací. M - městské kostely; V - vesnické kostely; K - klášterní kostely. 


\begin{tabular}{|c|c|c|c|c|c|}
\hline lokalita & okres & kostel & $\begin{array}{c}\text { založeno } \\
\text { (stáŕí) }\end{array}$ & $\begin{array}{c}\text { průzkum } \\
\text { (rok) }\end{array}$ & Poznámka \\
\hline Praha-Hradčany & - & katedrála sv. Víta & 1344 & $2001-2003,2005$ & $\begin{array}{c}\text { Maříková-Kubková et } \\
\text { al. 2005 }\end{array}$ \\
Vyšší Brod & Český Krumlov & Nanebevzetí P. Marie- K & 2. pol. 13. stol. & $2007-2011$ & $\begin{array}{c}\text { Hašek - Unger 2010, 49 } \\
\text { Hašek - Maštera - Šin- } \\
\text { delář - Thomová 2008; } \\
\text { Hašek - Unger 2010, 55 }\end{array}$ \\
\hline
\end{tabular}

Tab. 3. Církevní stavby prozkoumané geofyzikálními metodami v III. etapě těchto prací. M - městské kostely; V - vesnické kostely; K - klášterní kostely.

kého ověření. Tato měření uskutečnila fy. Geopek, spol. s r. o. Brno ve spolupráci se společností Isolines, s. r. o. Brno a v jednom prípadě (Svojšín) i Západočeským muzeem v Plzni. Účelem těchto předstihových průzkumů (tab. 2) bylo zjištění polohy jednotlivých hrobek a hrobů, stanovení jejich velikostí a hloubky založení, sledování reliktů zdiva ze starších staveb, upřesnění homogenity prostředí a litologických vlastností povrchových vrstev zemin a navržení perspektivních míst k situování př́padných plošných odkryvů, respektive sondáží.
V př́padě sakrálních staveb Křeč, Hostinné a Chýnov podalo geofyzikální měření upřesňující informace o možných reliktech staršího zdiva. U všech devíti lokalit byly získány podklady pro lokalizaci hrobek a prostých hrobů skrytých většinou pod novověkou kamennou nebo dřevěnou kostelní podlahou. Do třetí, závěrečné fáze těchto prací, částečně zahájené již v roce 2001 a pokračující s určitými přestávkami až do současnosti, patří nedestruktivní prospekce zahrnující metodu GPR, respektive i mikrogravimetrii, př́padně omezeně

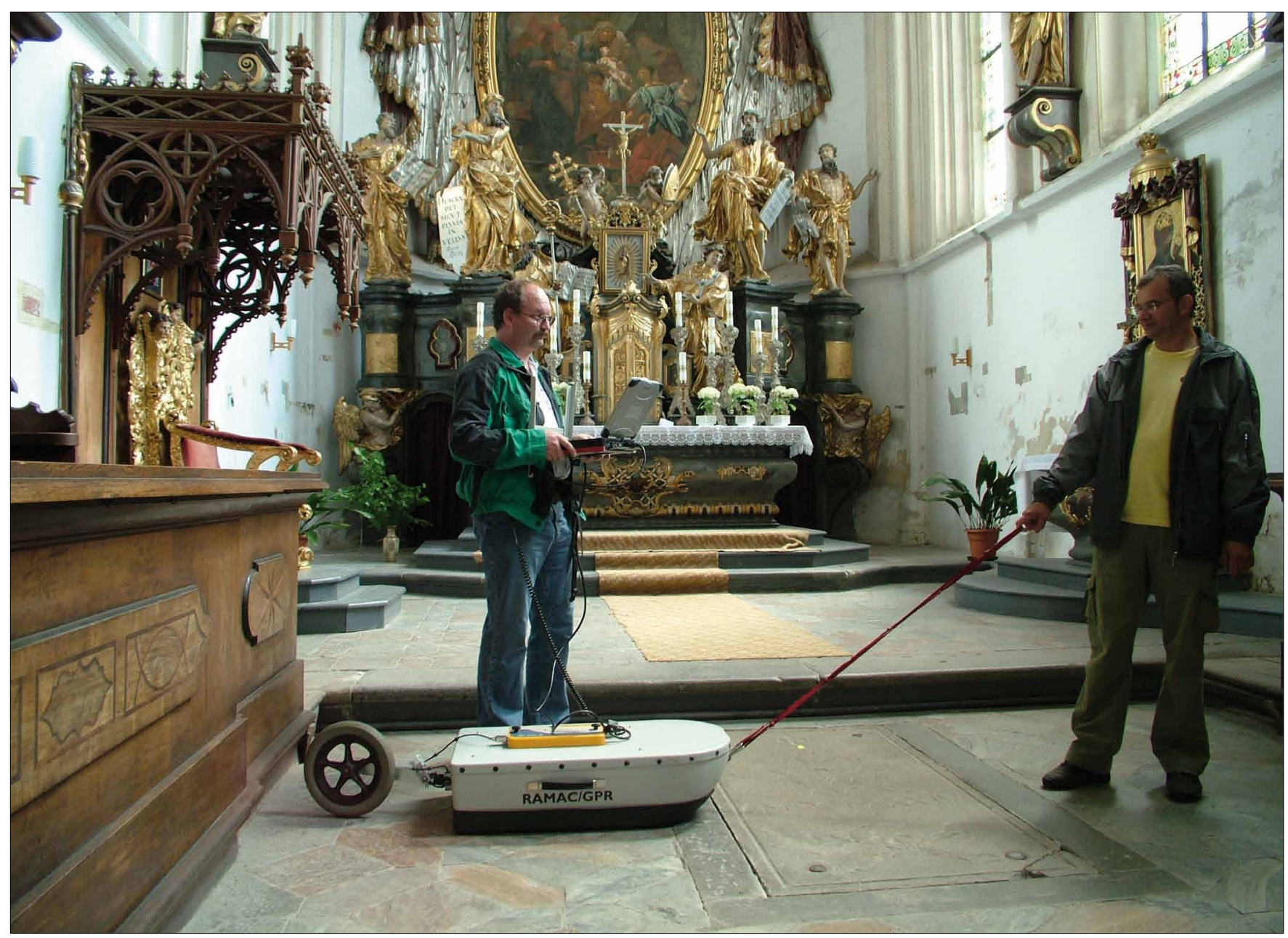

Obr. 2. Terénní měření georadarem, aparatura RAMAC X 3M/GPR - nejvíce používaná geofyzikální metoda k řešení uváděné problematiky. 
DEMP, doplněné dokumentací zjištěných struktur s ověřením kamerovým systémem.

Akcemi (tab. 3) realizovanými Archeologickým ústavem AVČR Praha a Geofyzikálním ústavem AVČR Praha v Praze-Hradčanech, dále firmou Geopek, spol. s r. o. Brno na dvou lokalitách Vyšší Brod a Želiv v kooperaci s Občanským sdružením Naše historie a organizací Geo-cz byly získány podrobné informace o konstrukci funerálních objektů, jejich velikosti, tvaru, stavebních fázích, vybavení a počtu pohřbených jedinců. $\mathrm{V}$ tomto př́padě jde prozatím o optimální nedestruktivní způsob průzkumu připovrchových podzemních dutých, prrípadně i částečně zavalených, prostor nacházejících se $\mathrm{v}$ interiérech církevních staveb.

Pro doplnění tab. 3 ještě uvádíme, že v roce 2010 bylo na Starém Městě pražském provedeno v presbytáři kostela sv. Haštala (1340-1375) na základě žádosti Národního památkového ústavu, územního odborného pracoviště v Praze dle dostupných pramenů (ČT, tisk) radarové měření amatérskými pracovníky s cílem př́padného nalezení avizovaných ostatků sv. Anežky České (†1282). Z údajů o výsledcích tohoto průzkumu (Dragoun - Podliska 2011, 27) vyplývá, že těmito pracemi byly zjištěny dvě indikace nehomogenit, $\mathrm{z}$ nichž prvá obsahovala výzkumem odkryté části zděných konstrukcí různého stáří, druhá pak, po celkovém ověření vrtem a minikamerou, rozměrnější barokní cihlovou hrobku $(4,2 \times 2,0 \times 3,6 \mathrm{~m})$ s několika dřevěnými rakvemi.

\section{VÝVOJ METODIKY TERÉNNÍCH GEOFYZIKÁLNÍCH PRACÍ}

$\mathrm{V}$ průběhu pokusných měření začátkem 80 . let minulého století, př́padně i později, se v Čechách uplatňovaly mikrogravimetrie, termometrie, eventuálně i odporové profilování, to znamená pouze geofyzikální metody, které měly $\mathrm{v}$ té době odpovídající přístrojové vybavení. Z těchto prací vyplynulo, že pro řešené úlohy se $\mathrm{v}$ interiérech staveb jeví jako vhodná především mikrogravimetrie (Hašek - Měřínský 1991). Postupně se však již v etapě systematické prospekce a testovacího výzkumu středověkých a novověkých hrobek a hrobů přecházelo od těchto mnohdy ekonomicky i provozně nákladnějších disciplín $\mathrm{k}$ mobilnějším a perspektivnějším metodám, $\mathrm{k}$ nimž náleží dipólové elektromagnetické profilování (DEMP) a po získání vhodných aparatur v druhé etapě (1999-2010) zejména půdní radar (GPR, georadar) (Hašek - Unger 2010, 11).

Z provedených geofyzikálních průzkumů v interiérech církevních staveb Čech (1979-2010) byly tyto metody na jednotlivých akcích (18) zastoupeny v následujícím pořadí: GPR (54,6 $\%)$, DEMP (18,2 \%), termometrie (13,6\%), mikrogravimetrie $(9,1 \%)$ a geoelektrické odporové měření $(4,5 \%)$.

1. Georadar (GPR, půdní radar) využívaný k lokalizaci hrobek, hrobů i reliktů zdiva vychází z obecného principu, že vysílačem elektromagnetických vln o frekvenci 100 až 500 $\mathrm{MHz}$ a současně i přijímačem odraženého signálu od vodivostního rozhraní v horninovém masívu je pohyblivá anténa umístěná těsně nad zemí. Aparatura odraz přijímá a zpra- covává na vhodném záznamovém zařízení, aby bylo možno po vykreslení odražených vln určit čas příchodu jednotlivých vln od doby vyslání elektromagnetického pulsu. Při terénních pracích se nad sledovaným horninovým prostředím anténa přemistuje po určité krokovací vzdálenosti, například $0,2-$ $0,5 \mathrm{~m}$, respektive se s ní pojíždí po povrchu terénu (obr. 2). Vzdálenost mezi profily dle terénní situace je 1-2 m. Výsledkem je časový řez proměřeného profilu (obdoba seizmického záznamu), získaný již v průběhu měření. Lze jej předběžně vyhodnotit př́mo na lokalitě (Hašek - Unger - Záhora 1997, 95). Praktické použití půdního radaru je založeno na zjištěných rozdílných relativních permitivitách a měrných odporech prostředí. Dosah metody závisí i na vyzářeném impulsním výkonu, anténě a citlivosti přijímače. $\mathrm{V}$ našich podmínkách nepřesáhne většinou $4-5 \mathrm{~m}$. K terénním pracím se používaly různé aparatury zahraniční provenience, nyní především RAMAC X3M/GPR švédské výroby (Geoscience Mala). Polohy výše uvedených lokálních nehomogenit v blízkosti povrchu se na jednotlivých změřených profilech projevují odrazy elektromagnetických vln ve tvaru pod sebou umístěných křivek podobných jednoramenným hyperbolám o různé šíri a orientaci (v závislosti na směru profilu a úhlu hledané struktury), eventuálně i přerušením průběhu odrazných horizontů. Obdobně se může projevit i větší sklon podložních hornin nebo blízká zástavba (obvodové zdivo budovy), kde dochází k výrazné difrakci elektromagnetických vln.

2. Metoda dipólového elektromagnetického profilování (DEMP) se používá od roku 2001 při sledování základového kamenného, případně cihlového zdiva u zaniklých staveb, hrobek, hrobů, respektive i dalších prvků spojených s uvedenými objekty, které se odlišují svými vodivostními vlastnostmi od okolního prostředí, tvořeného hlinito-písčitými zeminami a různými typy navážek. Terénní měření se provádějí od počátku aparaturou pro bezkontaktní měření zdánlivé vodivosti a magnetické susceptibility EM-38b-RT Geonics (Kanada), jejíž kmitočet je 13,2 KHz, vzdálenost mezi dipóly $1 \mathrm{~m}$ a hloubkový dosah ca 1,0-1,5 m. Krok měření na profilech je závislý na povaze řešeného úkolu; obvykle se pohybuje v síti $1 \times 1 \mathrm{~m}$; není však vyloučena ani sít $0,5 \times 0,5 \mathrm{~m}$. Vyhodnocení naměřených hodnot se provádí na $\mathrm{PC}$ ve formě map izolinií zdánlivých vodivostí, př́padně i magnetické susceptibility. Jednotlivé zkoumané objekty se v nich zobrazují jak lineárně orientovanými (zdivo, inženýrské sítě), tak i přibližně izometrickými pásmy (hrobky, hroby) převážně o snížených vodivostech.

3. Geotermika. Termické zjištování různých připovrchových nehomogenit $\mathrm{v}$ interiérech stávajících sakrálních staveb vychází z předpokladu jejich nestejného ochlazování nebo prohřivání. Změny závisí kromě kolísání teploty vzduchu v rámci denního a ročního cyklu také na proudění tepla $\mathrm{z}$ podloží stavby. Teplota povrchu není stálá a s časem se mění. Lokalizace nehomogenit indikované teplotními anomáliemi závisí na vhodné volbě doby (zejména zimní) $\mathrm{k}$ měření (Hrdlička - Nechvátal et al. 1983, 124). Vlastní průzkum - kontaktní i bezkontaktní se obvykle provádí na bodech $\mathrm{v}$ měřické síti ca $1 \mathrm{x} 1 \mathrm{~m}$ nebo $0,5 \mathrm{x} 0,5 \mathrm{~m}$. Prospekce v roce 1981 byla prove- 


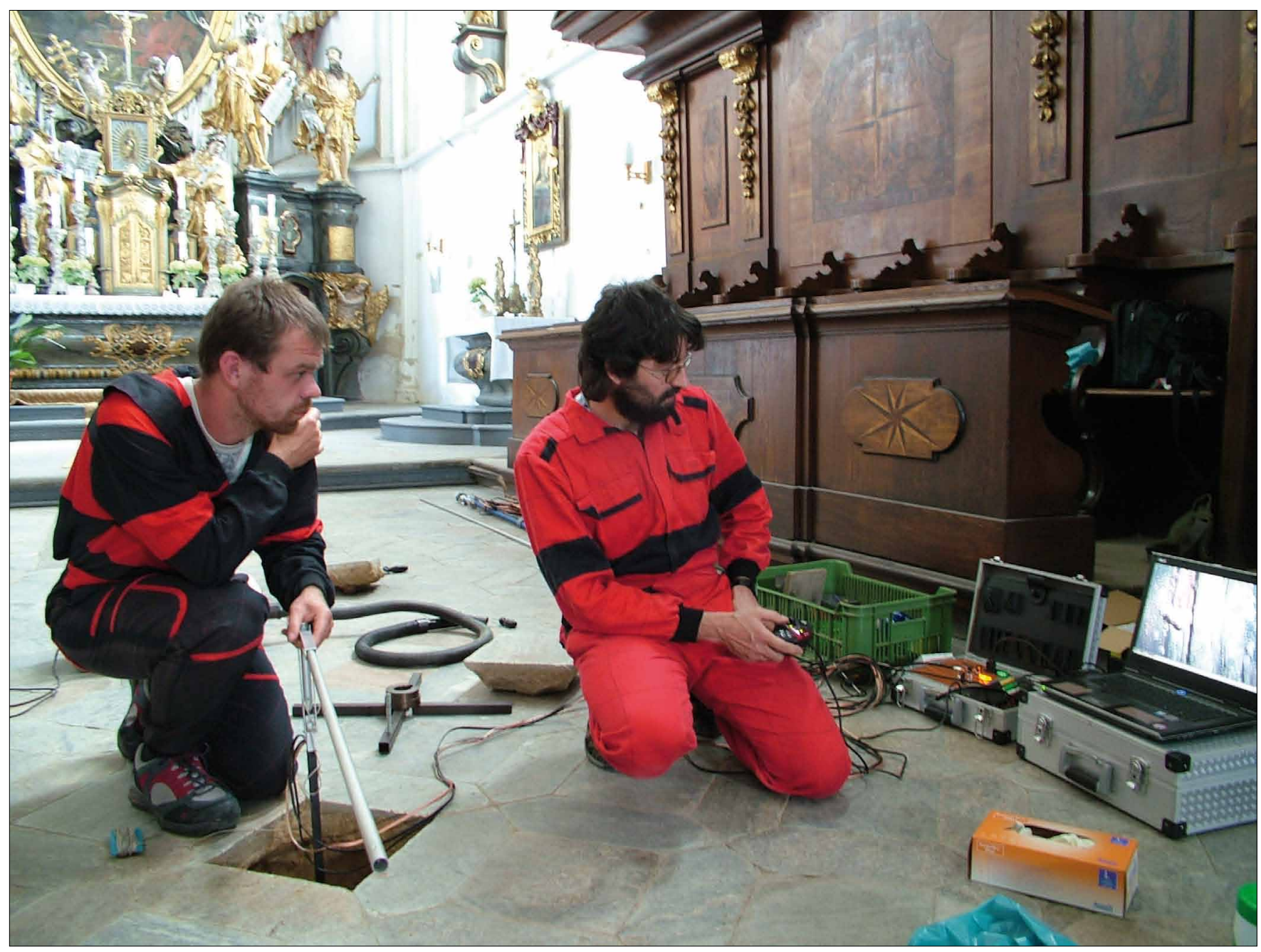

Obr. 3. Průběh vizuálního průzkumu minikamerou (Geo-cz).

dena infračerveným teploměrem KT-24 (Heiman Wiesbaden, Německo); v pozdějších letech (2001-2003) se využilo kontaktních teploměrů TM-908, nebo také GTH 1160 a infrateploměru GIM 1840-ST 60XB (Greisinger Electronic GmbH, Německo).

4. Mikrogravimetrie založená na diferenciaci přirozených hustot hornin nebo antropogenních objektů se použivala zejména při lokalizaci různých typů připovrchových dutin. Na zvolených bodech se měří změny tíhového zrychlení (tíže) vzhledem k hodnotám na základních gravimetrických bodech. Tíhový účinek anomálních připovrchových hustotních nehomogenit se získal z naměřené tíže odečtením teoretického účinku homogenní země a redukcí tíže na zvolenou nadmořskou výšku (Odstrčil in Hašek - Měřínský 1991, 45-46). K vlastnímu měření se $\mathrm{v}$ roce 1997 použily př́stroje Sodin a Canadian, které umožnily měřit tíži s přesností $\pm 0,07 \mathrm{~m}$ m.s-2. Anomálie, vyvolané hustotními nehomogenitami zájmových objektů (krypt, hrobek), se projevují jako tíhová minima dosahující dle modelování hodnot $\pm 0,1$ až $\pm 2,0$ m ms- 2 . Aby se mohly tak malé anomálie zjistit, použivala se speciální metodika měření i zpracování naměřených dat. Tíhové body se vytyčovaly v síti s krokem 0,5-3 m, eventuálně až 1,5x1,5 m. Pro průzkum v letech 2001-2003 se využil gravimetr La Coste Romberg D-188 (Geofyzikální ústav AVČR) s odečítací přesností 1 mokroGal $\left(=10^{-8} \mathrm{gcm}^{-2}\right)$.

5. Geoelektrická odporová měření. Tato prospekce byla provedena v areálu baziliky sv. Petra a Pavla v Praze na Vyšehradě v roce 1981 (Hrdlička - Nechvátal 1983, 126) s využitím atypického uspořádání elektrod. Byl měřen odpor velkoplošné kontaktní elektrody vůči elektrické zemnící síti v objektu. Vzdálenost bodů měření na profilech je $0,5 \mathrm{~m}$. Výsledky průzkumu byly zpracovány do mapy izoohm.

Od roku 2007 jsou údaje geofyzikálních prací v případě, že nelze v objektu nebo jeho blízkosti (obr. 3) realizovat vlastní archeologický odkryv, ověřovány především vizuálním průzkumem. K jeho řešení se používá speciální sonda sestrojená pro kamerovou dokumentaci staré královské hrobky v chrámu sv. Víta na Pražském hradě v roce 2005. Sonda se skládá z citlivé minikamery, laserových dálkoměrů, inkrementálního snímače a zařízení pro odběr vzorků. Celý systém je ovládán teleskopickým, robotickým ramenem s dosahem $10 \mathrm{~m}$ od vstupního otvoru. Pro komplexní průzkum podze- 
mí stačí realizovat pouze vývrt o průměru $3 \mathrm{~cm}$. Výsledkem je kvalitní, barevný videozáznam podzemního objektu (vizuální průzkum) a podrobné plány (v podobě půdorysu, řezu a nástavbově i 3D model objektu). Pro mapování zkoumaného objektu byla zvolena kombinace polární metody a průsekové fotogrammetrie. Pomocí laserových dálkoměrů a inkrementálního snímače je $\mathrm{v}$ interiéru zaměřen dostatečný počet přirozených vlícovacích bodů, které jsou využity pro orientaci měřických snímků, pořízených kalibrovanou kamerou. Tímto způsobem je možné v souřadnicích $\mathrm{X}, \mathrm{Y}$ a $\mathrm{Z}$ zaměřit i ty nejmenší detaily uvnitř nepřístupného objektu.

\section{DISKUSE PRAKTICKÝCH VÝSLEDKŮ NEDESTRUKTIVNÍCH METOD PROSPEKCE}

$\mathrm{V}$ následujících odstavcích našeho příspěvku se zabýváme prezentací hlavních údajů dosažených geofyzikální prospekcí v kombinaci s archeologickým výzkumem, respektive dokumentací při řešení problematiky církevních staveb ve III. etapě těchto prací na území stř̌edních a jižních Čech. Za typické příklady můžeme považovat následující výsledky prací z lokalit Praha-Hradčany, Vyšší Brod (okr. Český Krumlov) a Želiv (okr. Pelhřimov) (obr. 1).

\section{Praha-Hradčany, katedrála sv. Víta}

Impulsem pro stavebně historický a archeologický výzkum v chóru katedrály sv. Víta v letech 2001-2003 a následně v roce 2005 byly schematické podkladové materiály J. Rockera, uveřejněné v práci Emanuela Vlčka (Vlček 1999-2000). Jednalo se zde o lokalizování možné královské hrobky v prostoru pod hlavním oltářem, jejíž eventuální zjištění by přispělo k poznání různých stavebních fází gotického chrámu i destrukcí starších staveb ve zkoumaném areálu (Maříková-Kubková - Bra-

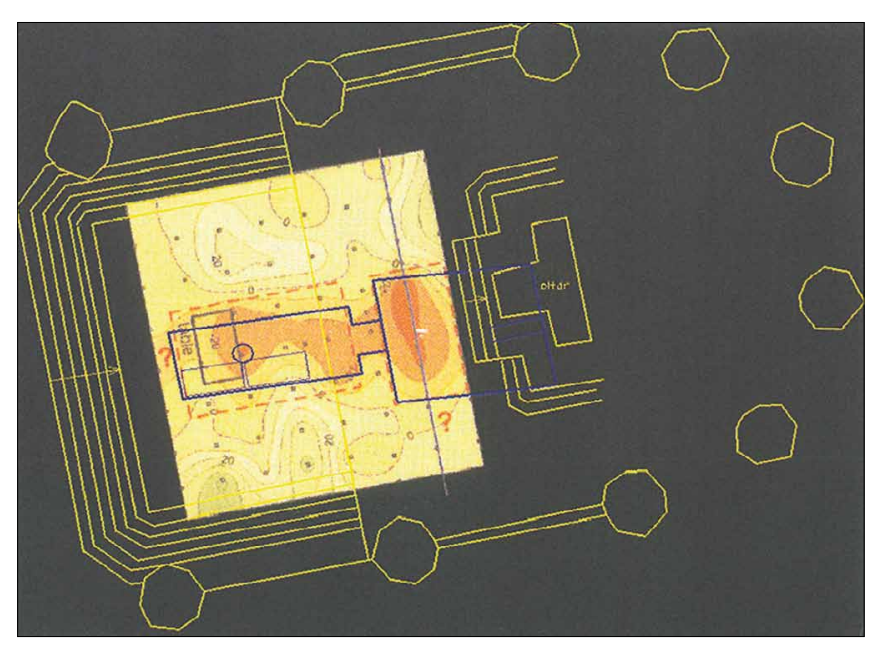

Obr. 4. Praha-Hradčany: Mikrogravimetrie, mapa reziduálních tíhových anomálií ve skutečné poloze realizovaného měření - porovnání s půdorysem hrobky (Mrlina in Maříková-Kubková - Bravermanová - Kováč et al. 2005).

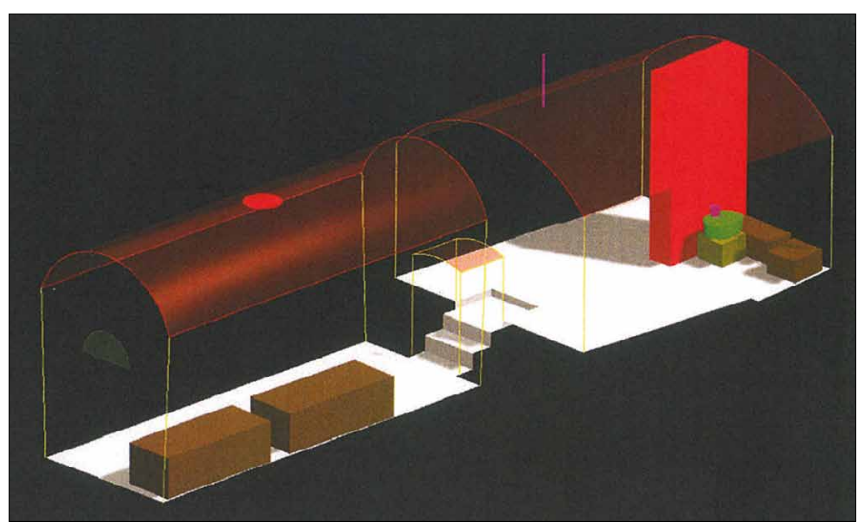

Obr. 5. Praha-Hradčany: Model královské hrobky (Geo-cz).

vermanová - Kováč et al. 2005, 99). Na této činnosti s cílem př́ípadného vysledování uvedeného objektu se podílela řada odborných pracovníků $\mathrm{z}$ různých vědních oborů. Celkový postup prací byl z metodického hlediska rozvržen do několika částí. V první etapě (2001-2003) byly v předmětném prostoru uplatněny nedestruktivní geofyzikální metody - mikrogravimetrie, termometrie a částečně i DEMP, jejichž úkolem bylo určit, zda se zde nachází dutý prostor. Výsledky mikrogravimetrického měření (Mrlina, GÚ AVČR Praha) byly zpracovány do mapy tíhových a reziduálních anomálií (+10 až -60 mGAL) (obr. 4). Poměrně výrazné negativní indikace naznačují existenci připovrchové podzemní prostory obdélníkového půdorysu (ca $7 \times 3,5 \times 2,5 \mathrm{~m}$ ) s vrcholem v hloubce $1,5 \mathrm{~m}$. Opakovaným termickým měřením (Křivánek - ArÚ AVČR Brno, Majer) se v místech negativní tíhové anomálie zjistily v zimních měsících kladné anomální hodnoty $\left(1,2-1,5^{\circ}\right.$ C), v letním období naopak korelovatelné nízké (záporné) hodnoty, jejichž tvar, amplituda a velikost se časově měnily. Uplatněná metoda DEMP detekovala, vzhledem k rozsáhlým recentním rušivým vlivům, pravděpodobně pouze relikty zdiva hrobky. Z naměřených zvýšených hodnot magnetické susceptibility bylo možno usuzovat na vyšší obsah kovového materiálu v dutém prostoru pod povrchem terénu.

\section{Stavebně historické a archeologické posouzení zjištěné situace}

V etapě prací roku 2005 byly hlavní geofyzikální anomálie $\mathrm{z}$ mikrogravimetrie a termometrie ověřeny úzkoprůměrovým vrtem a dokumentovány mikrokamerou s cílem ověřit předpokládaný dutý prostor. Touto činností byly získány poměrně přesné informace o hrobce, jejím obsahu i aktuálním stavu. Vlastní funerální objekt, postavený z pískovcových kvádrů s cihlovou a vyzdívkovou klenbou, sestává ze dvou komor nepravidelně obdélného půdorysu situovaných pod chórem. Jsou umístěny za sebou v ose V - Z mezi hlavní oltář a oltářní stůl (obr. 5). Východní komora (obr. 6) o rozměrech $4,6 \times 4,7 \times 3,7-3,8 \times 2,8 \mathrm{~m}$ obsahuje dvě dřevěné rakve s kosterními pozůstatky a menší oválnou kovovou nádobou o velikosti ca $0,5 \times 0,6 \times 0,2 \mathrm{~m}$. Podél celé severní stěny hrobky jsou frag- 


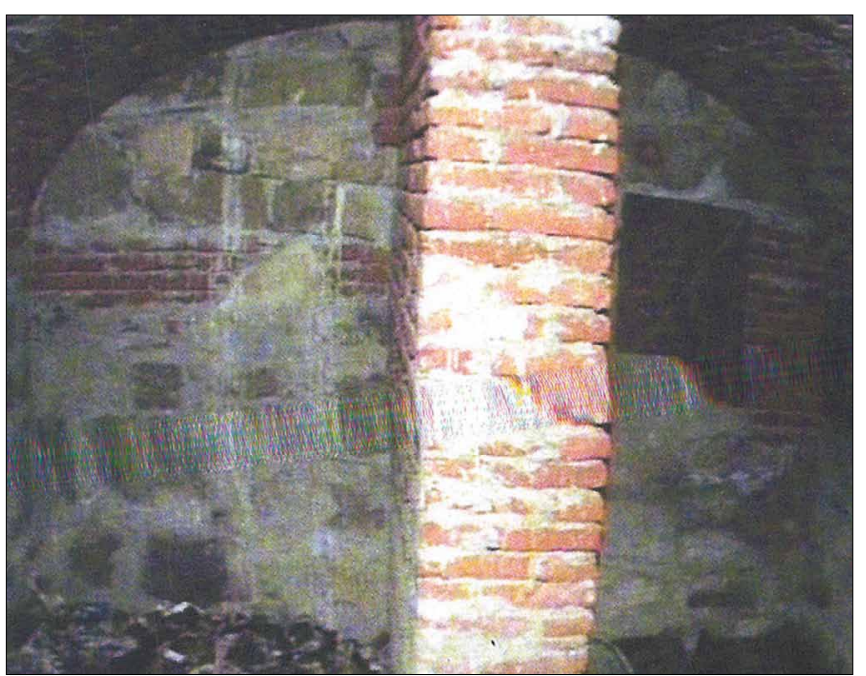

Obr. 6. Praha-Hradčany: Pohled na východní stěnu východní královské krypty $(\mathrm{Geo}-\mathrm{cz})$

menty různě značně poškozených rakví s kosterními pozůstatky; v její západní části se nacházejí menší barokní kovové předměty související $s$ pohřby. $\mathrm{V}$ západní komoře o velikosti ca $2,4-2,5 \times 6,2 \times 2,6-3,5 \mathrm{~m}$ byly zjištěny dvě truhly o rozměrech $2 \times 0,8 \times 0,74 \mathrm{~m}$, které sloužily $\mathrm{k}$ deponii rozpadlých rakví.

Vlastní hrobku vybudoval Karel IV. (Maříková-Kubková Bravermanová - Kováč et al. 2005, 102). Postupně byli do ní umístováni zemřelí členové jeho rodiny, a to Anna Svidnická (†1362), Karel IV. (†1378), Alžběta (Eliška) Pomořanská (†1393), Jan Zhořelecký $(\dagger 1396)$, Václav IV. (†1419), dále Ladislav Pohrobek (†1457), Jiř́ z Poděbrad (†1471), z Habsburků Ferdinand I. (†1564), Maxmilián II. (†1576) a Anna Jagellonská (†1547). Pro úplnost dodáváme, že z podnětu císaře Rudolfa II. byla $\mathrm{v}$ roce 1566 zahájena západním směrem od stávajících komor výstavba nové hrobky s nadzemním mauzoleem, dokončené $\mathrm{v}$ roce 1589 , do které byly následně přeneseny všechny ostatky z původního objektu. Stará hrobka byla pak používána $\mathrm{k}$ pohřbívání vysokých církevních hodnostářů po celé 17. a 18. století (Maříková-Kubková - Bravermanová - Kováč et al. 2005, 102-103).

\section{Vyšší Brod, cisterciácký klášter s kostelem Nanebevzetí P. Marie}

Rozlehlý klášterní areál převzal označení po obci Vyšší Brod $\mathrm{v}$ Jihočeském kraji. Je postaven na vyvýšenině na pravém břehu Vltavy. V geomorfologickém členění zaujímá obec pozici v Českokrumlovské vrchovině, jež je součástí Šumavského podhůří. Meandrující Vltava, tekoucí obcí od severozápadu k jihovýchodu, přibírá od jihozápadu Menší Vltávku. Na jejím jižním konci, kde Vltava pokračuje k východu, ústí od jihu další drobné dva potoky. Celá obec včetně kláštera se nalézá na širokém výnosovém vějiŕi Menší Vltávky a obou blízkých potokủ, které celé splývají do mohutného dejekčního kužele. Lemuje v délce asi $1,5 \mathrm{~km}$ pravý vltavský břeh. Tyto holocenní

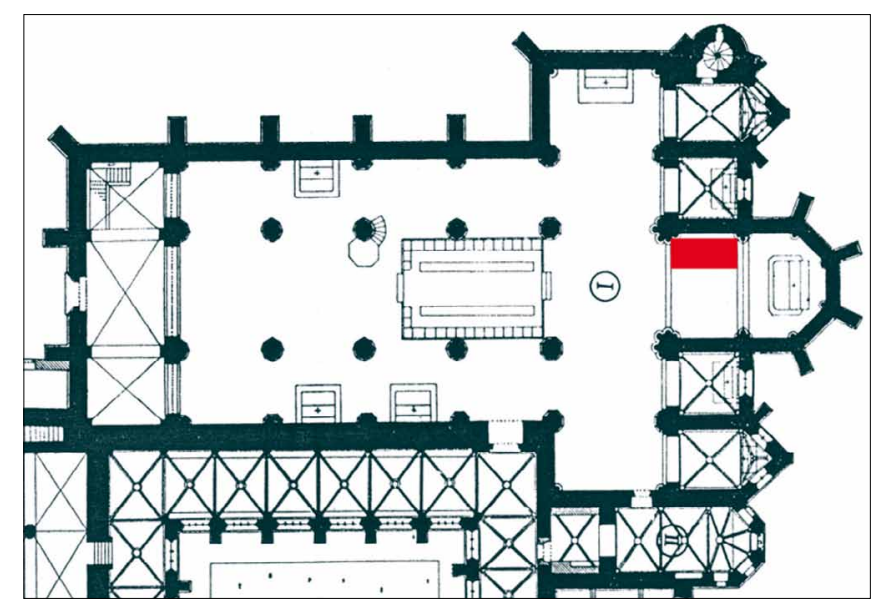

Obr. 7. Vyšší Brod: Poloha rožmberské hrobky v klášterním kostele Nanebevzetí P. Marie (Naše historie, o. s.).

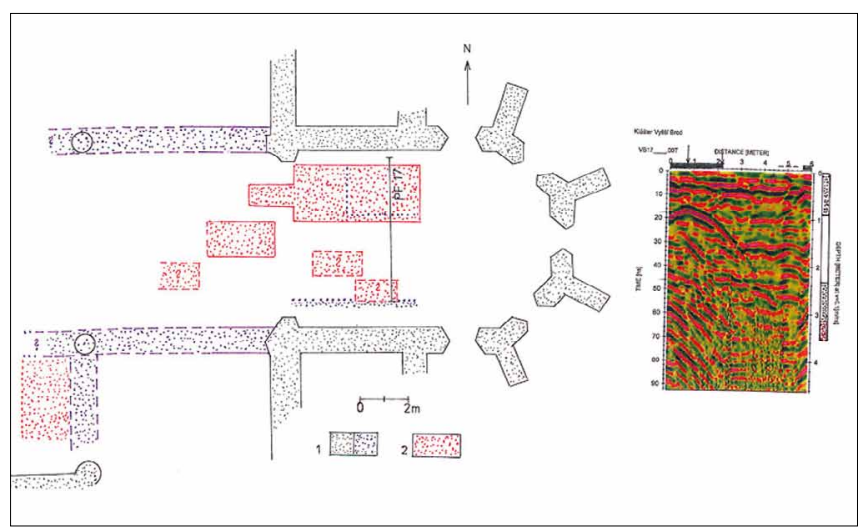

Obr. 8. Vyšší Brod: Interpretované objekty a zpracovaný radarogram v prostoru presbytáře klášterního kostela Nanebevzetí P. Marie.

a pleistocenní sedimenty tvoří deluviální a deluviosoliflukční kamenitohlinité a kamenitopísčité sedimenty. Lze předpokládat, že návrší, na němž klášterní komplex spočívá, bude mít pod recentním antropogenním pokryvem jen malou mocnost či relikt deluviálních sedimentů a je spíše projevem nehlubokého skalního žulového podloží.

Vlastní centrum kláštera, založeného Vokem z Rožmberka roku 1259, tvoří kostel s ambitem po jižní straně, na východní straně menší dvůr se starým konventem a k němu na sv. připojené opatství. Konventní chrám s prìilehlými budovami byl stavěn postupně od 60 . let 13 . století a dokončen byl v 80 . letech 14. století (Poche et al. 1982, 310-317). V šedesátých až osmdesátých letech 13. století byla postavena východní část kostela s presbytářem a příčná lod’s bočními severními kaplemi sv. Benedikta a sv. Kříže, jižními sv. Bernarda a P. Marie. Specifickým slohovým projevem je klenba kapitulní síně (kolem roku 1285). Křížová chodba byla postavena v průběhu 14. století. $\mathrm{V}$ roce 1422 došlo $\mathrm{k}$ vypálení kostela husity a větší opravy a rekonstrukce $\mathrm{v}$ novogotickém slohu byly provedeny v letech 1830-1860, kdy byla přistavěna i kostelní věž (Vlček - Sommer - Foltýn 1997, 688-691). 


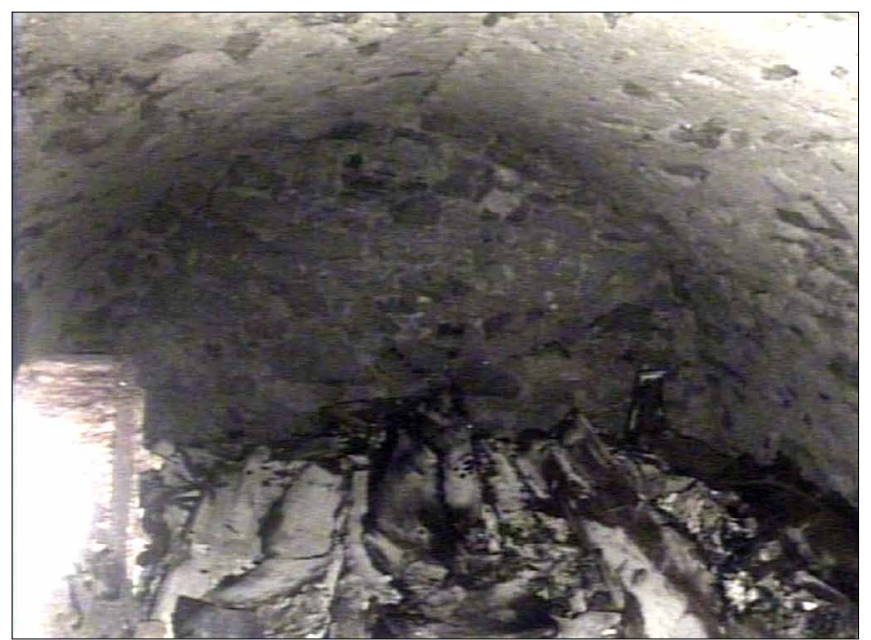

Obr. 9. Vyšší Brod: Rožmberská hrobka, pohled na východ (Naše historie, o. s.).

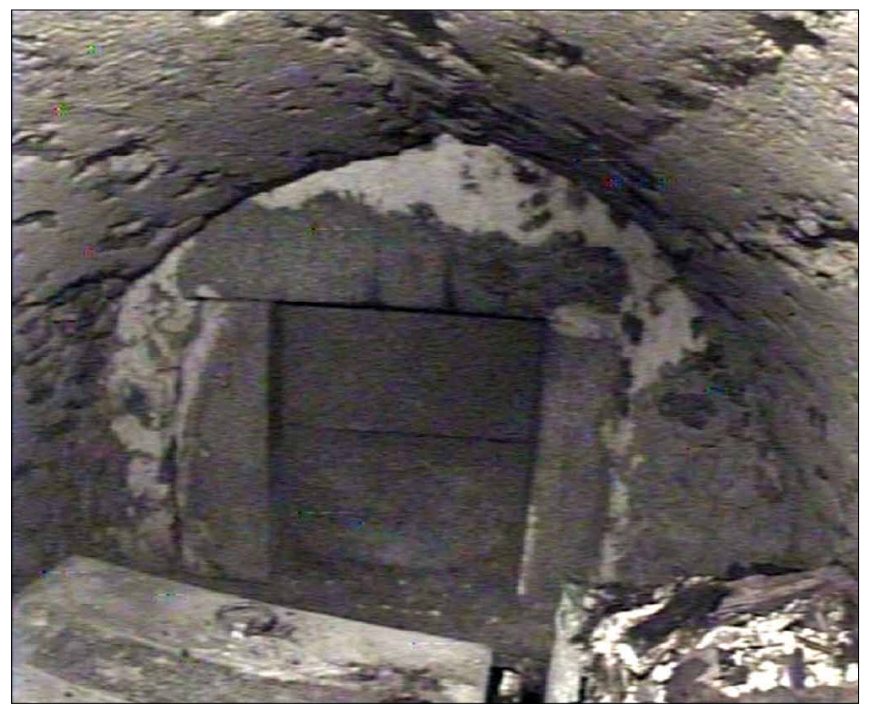

Obr. 10. Vyšší Brod: Rožmberská hrobka, pohled na západ (Naše historie, o. s.).

Cílem a hlavním úkolem archeogeofyzikální prospekce, která tvořila součást projektu občanského sdružení Naše historie, Jihočeského muzea v Českých Budějovicích a dalších zainteresovaných organizací z celé České republiky v roce 2007 (Hašek - Tomešek 2009, 14), bylo poskytnout podrobnější informace o možné větší rožmberské hrobce, případně také o menších hrobkách z různých období existence kláštera, reliktech zdiva a mocností antropogenních či jiných uloženin (obr. 7).

$\mathrm{Z}$ údajů aplikované metody GPR lze na proměřených profilech $\mathrm{z}$ výraznějších odrazů elektromagnetických vln na menších časech ( $\mathrm{t}=32-60 \mathrm{~ns})$ předpokládat relativně nehomogenní prostředí do hloubek řádově $1,9 \mathrm{~m}$ až $3,5 \mathrm{~m}\left(\mathrm{v}_{\mathrm{r}}=0,12 \mathrm{~m} / \mathrm{ns}\right)$. Vzhledem k pravděpodobnému pozvolnějšímu litologickému přechodu mezi antropogenním pokryvem a kvartérním zvětralinovým pláštěm může jít o určité fiktivní rozhraní mezi vrstvou těchto uloženin a povrchem rozvětralých hornin moldanubického plutonu (Hašek - Unger 2010, 51).

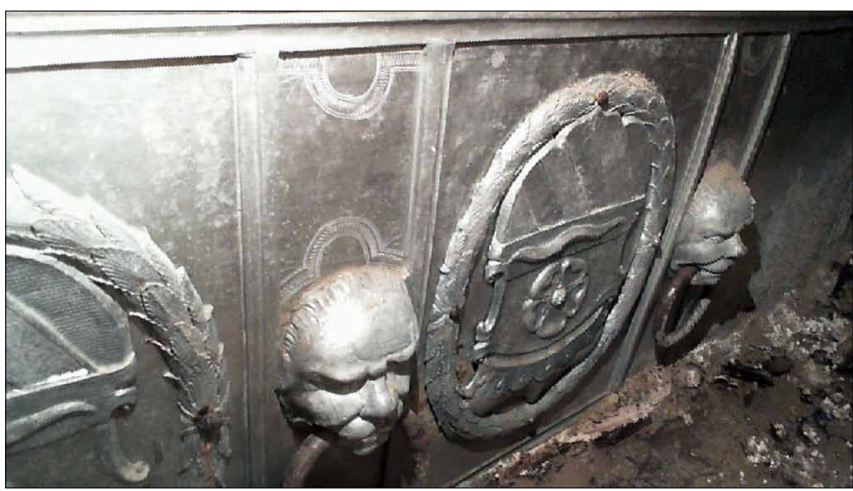

Obr. 11. Vyšší Brod: Bok rakve Petra Voka zdobený obrácenými Rožmbersko-Ursinovskými erby (Naše historie, o. s.).

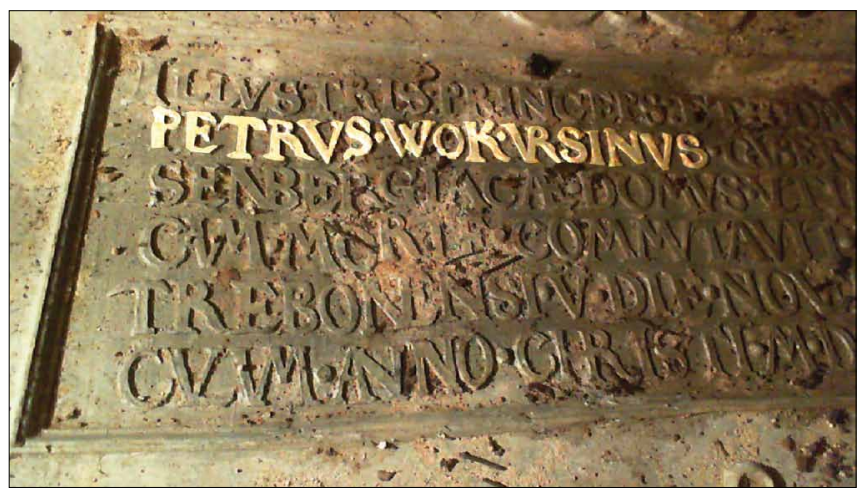

Obr. 12. Vyšší Brod: Autentika z rakve Petra Voka (Naše historie, o. s.)

$\mathrm{V}$ areálu kláštera bylo $\mathrm{z}$ hlediska možného projevu hrobek vyčleněno 11 geofyzikálně různě výrazných indikací, které se nacházejí především v interiéru kostela Nanebevzetí P. Marie (8), několik dalších pak v křížové chodbě (2) a kapitulní síni (1). Za velmi výraznou můžeme považovat nehomogenitu na evangelijní straně presbytáře o interpretovaných rozměrech ca $5 \times 3 \mathrm{~m}$ a hloubce vrcholu v ca $0,8-1,0 \mathrm{~m}$. $\mathrm{Z}$ dostupných pramenů bylo zjištěno, že když v roce 1902 došlo $\mathrm{k}$ poklesu stupňủ hlavního oltáře chrámu, provedené sondážní práce odkryly v těchto místech klenbu. Pod ní se nacházela prostora se zbytky dřevěných truhel a dvě cínové rakve. Nelze vyloučit předpoklad, že může jít o jednu z př́ípadných rožmberských hrobek. V letech 1262 až 1612 mělo zde být pohřbeno na 36 př́slušníků rožmberského rodu a tři příslušníci krumlovské větve. Dalším zpracováním naměřených radarogramů bylo zjištěno, že lokalizovaný pravděpodobně dutý prostor bude hlubší, než se původně očekávalo, a to o ca $1,5 \mathrm{~m}$ (obr. 8).

Velmi výrazná, ovšem plošně menší nehomogenita o rozměrech ca $2,5 \times 1,5 \mathrm{~m}$ a hloubce $0,5-0,6 \mathrm{~m}$ byla vyčleněna $\mathrm{v}$ boční kapli sv. Benedikta. Jde o hrobku krytou náhrobníkem Jana Zrinského (†1612).

Proměnně výrazné nehomogenity v kaplích sv. Kříže, sv. Bernarda a P. Marie souvisejí podle náhrobních desek opatů $\mathrm{z}$ let 1578 až 1766 pravděpodobně s jejich hrobkami, dnes částečně nebo i úplně zanesenými sedimentem. Další indikace připo- 


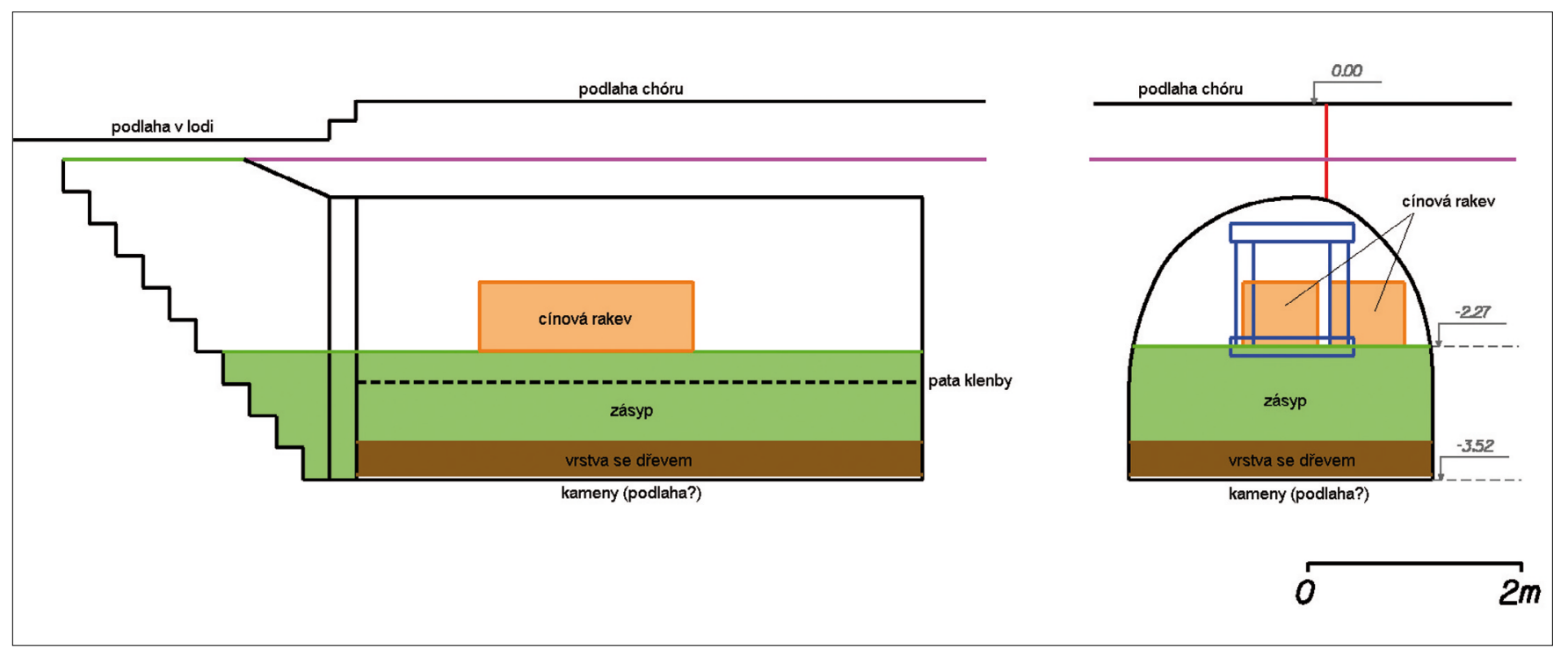

Obr. 13. Vyšší Brod: Sondáží ověřená rožmberská hrobka se zásypem (Naše historie, o. s.).

vrchových nehomogenit v prostoru kostela i kláštera mohou odpovídat i menším hrobkám a hrobům zde pohřbených církevních hodnostářò.

\section{Stavebně historické a archeologické posouzení zjištěné situace}

Z archeologického hlediska byla roku 2009 ověřena vrtem a minikamerou pouze připovrchová nehomogenita na evangelijní straně presbytáře, nad níž je v severní zdi kostela zazděn kámen $\mathrm{z}$ růžového mramoru s vyobrazením rožmberského jezdce na koni. Jeden $\mathrm{z}$ přeložených latinských nápisů na něm zní: „Zde je hrob pánů z Rožmberka, zakladatelů tohoto místa s předností původu od knížat Orsini“. Archeologické ověření z roku 2009 (Naše historie o. s., Jihočeské muzeum v Českých Budějovicích) zjistilo v uvedeném prostoru dutou hrobku o rozměrech 5,4 x 2,4 x 1,5 m (obr. 9, 10), která obsahovala dva cínové sarkofágy a větší počet rozpadlých dřevěných rakví. Jeden sarkofág patřil Petru Vokovi (†1611) (obr. 11,12 ), druhý se nepodařilo jednoznačně ztotožnit $s$ žádnou konkrétní historickou osobností. Následující průzkum v roce 2011 (Naše historie o. s.) potvrdil výsledky geofyziky v tom smyslu, že dno uvedeného objektu není podlahou, ale mohutnou zásypovou vrstvou o mocnosti ca $1,3 \mathrm{~m}$. V hloubce 0,90-1,10 m byly ve vzorcích sedimentu rozpoznány kousky zetlelého dřeva a $\mathrm{v}$ hloubce $1,25-1,30 \mathrm{~m}$ vrstva $\mathrm{z}$ kamenů (původní kamenná dlažba?). Odebrané vzorky sedimentu byly testovány na obsah fosfátů. Touto chemickou analýzou byl potvrzen výrazný nárůst obsahu fosfátů v hloubce 1,10$1,20 \mathrm{~m}$ pod současným dnem hrobky. Všechna zjištění tak poukazují na to, že původní rožmberská hrobka byla výrazně hlubší než dnes (minimálně 2,70 m). Po zaplnění hrobky pohřby byla tato zavezena přibližně metr mocným zásypem (tím „přepatrována“) a další členové mocného šlechtického rodu tak mohli být nadále pohřbíváni ke svým předkům (obr. 13).

\section{Želiv, klášter premonstrátů s kostelem Narození P. Marie}

Obec Želiv se nalézá v Želivské pahorkatině, jež je součástí Křemešnické vrchoviny v západní části Českomoravské vrchoviny. Byla založena $\mathrm{v}$ hlubokém až kaňonovitém údolí, které vytvořila řeka Želivka. Stř̌edověký klášter byl vybudován na ostrohu, který se vytvořil na soutoku Želivky s meandrující ŕíčkou Trnávkou. Komplex klášterních budov postavených z hornin biotit-silemanitické pararuly pestré série moldanubika spočívá na deluviálních sedimentech o proměnných mocnostech, které lemují ostroh.

Premonstrátský, původně benediktinský klášter Želiv byl založen v újezdu pražského biskupa (Hašek - Maštera - Šindelář - Thomová 2008, 6). Klášterní tradice spojuje akt fundace s knížetem Soběslavem I. a jeho manželkou Adlétou. Písemné zprávy pak udávají rok 1144, kdy Vladislav II. daroval statek Želiv pražskému biskupovi Otovi a krátce nato zde vznikl benediktinský klášter. V roce 1148 benediktini Želiv opustili a na jejich místo byl povolán premonstrátský konvent, který přišel do Želiva v roce 1149. V letech 1420-1424 byl klášter $\mathrm{v}$ důsledku husitských nepokojů značně poškozen. Kostel i klášterní budovy byly husity vypáleny a teprve v roce 1462 došlo v Želivě k obnovení řeholního života. V roce 1623 přechází želivský klášter pod správu Strahova a do tohoto období spadají i výraznější snahy o obnovu zchátralých klášterních budov a kostela (Wirth 1908, 121-56; Kalista 1970, 32-33). $\mathrm{V}$ roce 1643 byl klášter obnoven jako samostatný konvent. $\mathrm{V}$ 17. a následném 18. století došlo $\mathrm{k}$ výraznému rozvoji kláštera a rozsáhlé stavební činnosti (Charouz 1995; Vlček - Sommer - Foltýn 1997, 703-709).

Při místním šetření v kostele Narození P. Marie v březnu 2007 bylo shledáno, že ve stávající úrovni dnešní podlahy je patrno celkem pět kamenných náhrobních kamenů opatů, bratří, 


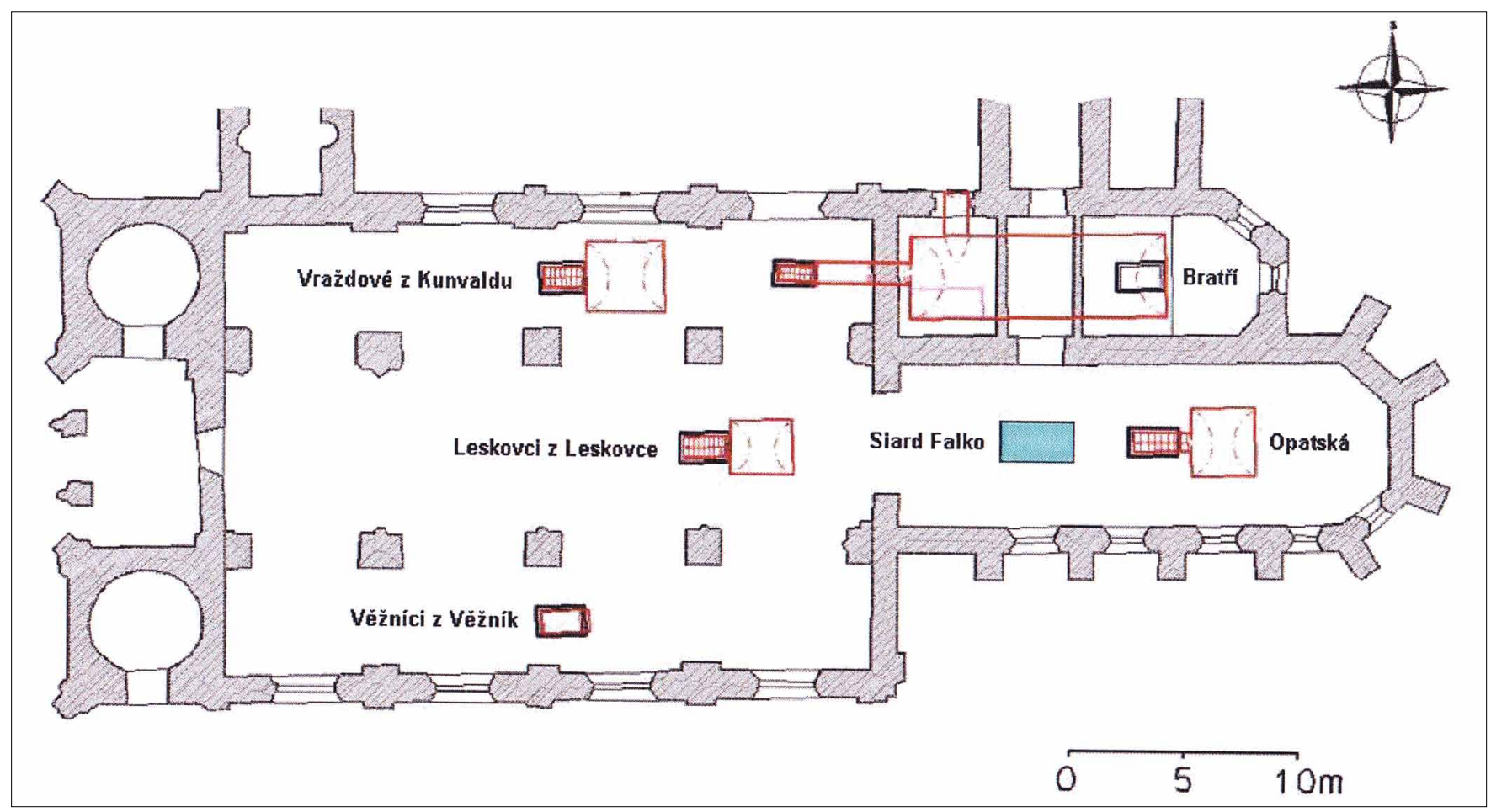

Obr. 14. Želiv: Půdorysný plán lokalizovaných hrobek ve zkoumaném klášterním kostele Narození P. Marie (Geo-cz).

rytírů Vraždů z Kunvaldu, Leskovců z Leskovce a Věžníků z Věžník. Cílem geofyzikální radarové prospekce, uplatněné v rámci řešení úkolu občanského sdružení Naše historie a Jihočeského muzea v Českých Budějovicích v roce 2007, bylo ověřit polohy a rozměry př́padných hrobek v místech náhrobních kamenů a poskytnout informace o polohách dalších dosud nezmapovaných funerálních a jiných objektů v interiéru uvedené stavby. Metodou GPR a dokumentačním minikamerovým systémem (Geo-cz) se prozkoumalo celkem šest podzemních prostor (obr. 14), které se nacházely na různých místech v objektu. Vesměs se jednalo o hrobky, do nichž byli ukládáni zesnulí nějakým způsobem spojení s klášterem a konventním kostelem (Hašek - Unger 2010, 56).

\section{Stavebně historické a archeologické posouzení zjištěné situace}

Z výsledků prospekce a vizuálního průzkumu (Geo-cz) vyplynuly tyto závěry: $\mathrm{V}$ opatské hrobce o rozměrech $2,8 \times 2,8 \times 1,9 \mathrm{~m}$, vybudované před hlavním oltářem, byli uloženi významní barokní opati. Vznik a vybudování této klenuté cihlové hrobky lze i na základě datace s vyobrazením křiže na východním zdivu a na základě datace náhrobního kamene, kterým je zakryt vstup do hrobky, položit do let 1682-1684. Posledním opatem uloženým do hrobky byl Arnošt Morávek (1752-1775). $\mathrm{V}$ hrobce se nachází několik pohřbů, ale jasně čitelné jsou pouze dva (pohřeb uprostřed krypty a na pravé jižní straně). Dřevěná schránka na ostatky je umístěna $\mathrm{v}$ severozápadním rohu (obr. 15). Jeden z pohřbů je uložen do ručně tesané dře- věné rakve s dřevěnýma kulatýma nohama a s největší pravděpodobností je uložen na katafalku bez víka; pouze přes obličej je zakryt pohřebním závojem. Je orientován hlavou k oltáři, tedy na východ, leží na zádech, ruce má složené na břiše a viditelné jsou ještě zbytky opatských rukavic (obr. 16). Na krku má zavěšen na řetízku kovový kříž (obr. 17) a na nohou zbytky obuvi (obr. 18). Pohřeb u jižní zdi hrobky je podstatně hưř̀ dochován. Zesnulý je uložen na zádech v dřevěné rakvi vy-

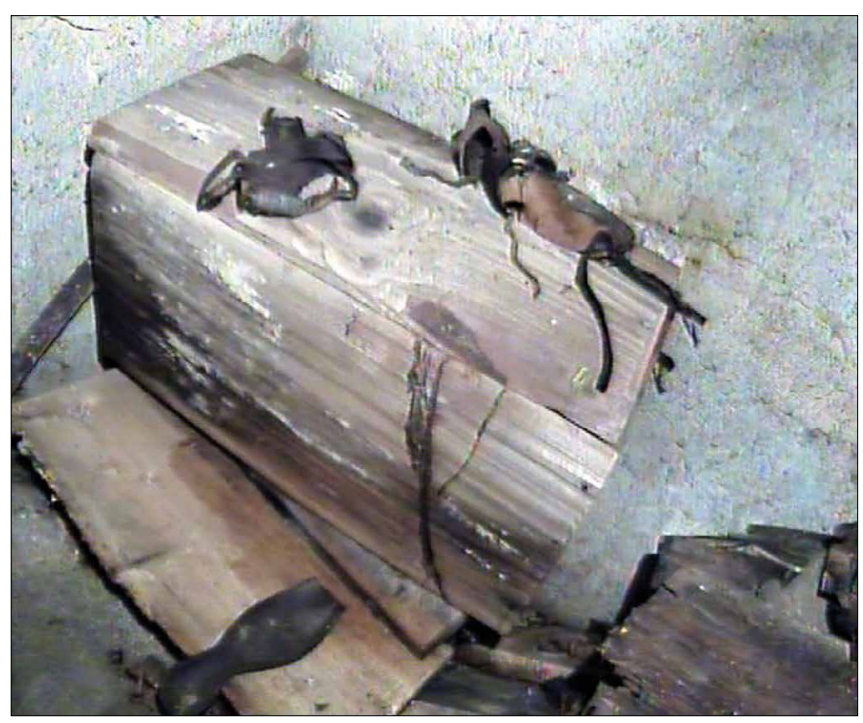

Obr. 15. Želiv: Opatská hrobka. Dřevěná schránka na ostatky v severozápadním rohu s fragmenty kožených bot (Geo-cz). 


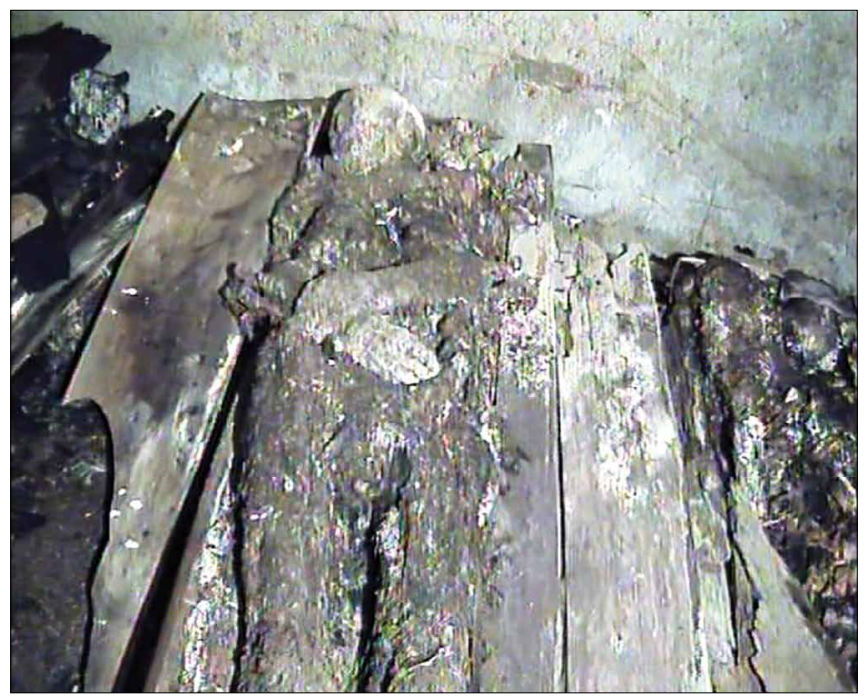

Obr. 16. Želiv: Opatská hrobka. Jeden z posledních hrobů (Geo-cz).

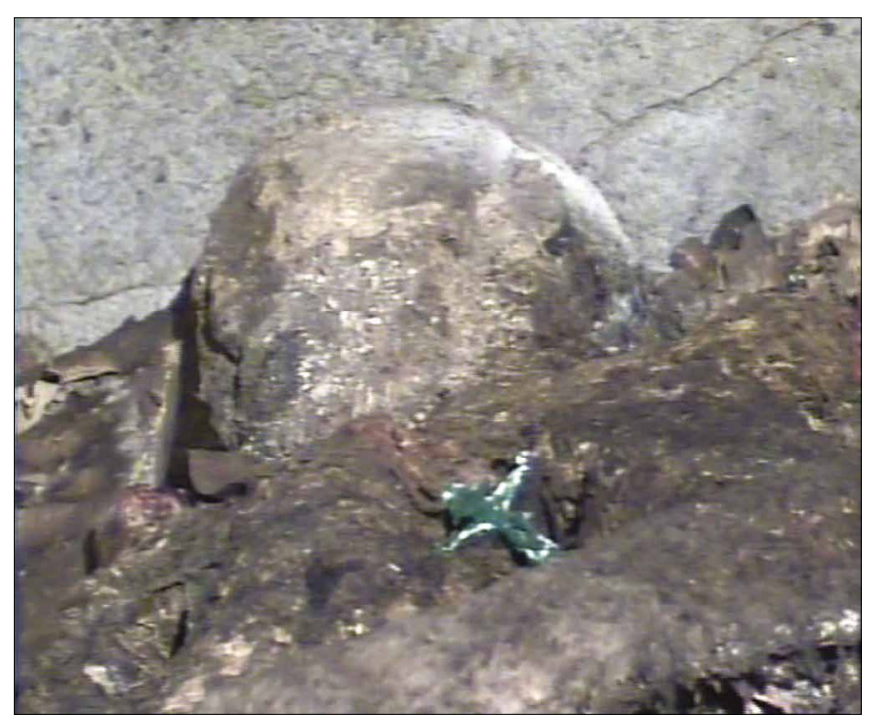

Obr. 17. Želiv: Opatská hrobka. Detail horní části těla s kovovým kř́žžkem (Geo-cz).

plněné hoblinami hlavou k oltáři. Ruce má nebožtík složeny na břiše a na hlavě jsou zbytky pokrývky. Na hrudi je umístěn větší dřevěný kř́iž opatřený měděným plechem. Celý pohřeb je ve značném stupni rozkladu a je, na rozdíl od pohřbu předcházejícího, méně čitelný. Pohřby vlevo na severní straně jsou také nečitelné, spíše se jedná o kumulaci dřevěných prken, lidských pozůstatků, látkových př́krovů a výplní rakví z více pohřbů. Těsně u paty zaklenutí vstupu na severní straně jsou v malých dřevěných truhlách zřejmě druhotně uloženy další pozůstatky.

V kostele byla zkoumána také hrobka bratří a další tři hrobky, které patřily šlechtickým rodům. Kromě těchto výše uvedených objektů se západně od opatské hrobky geofyzikálně lokalizovala další dosud neznámá menší hrobka, která podle vyzvednuté a restaurované autentiky (uloženo $\mathrm{v}$ depozitáři

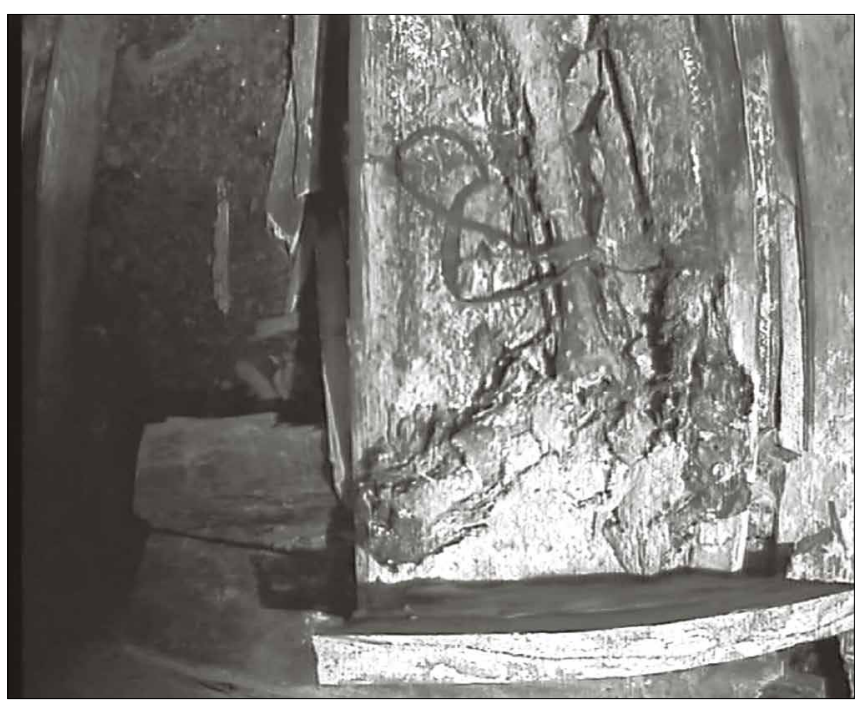

Obr. 18. Želiv: Opatská hrobka. Detail pravé nohy se zbytkem obuvi (Geo-cz).

Jihočeského muzea v Českých Budějovicích) náležela opatu Siardu Falkovi. V místech hlavní a bočních lodí se kromě zjištěných hrobek předpokládají hroby, pravděpodobně částečně zavalené, s orientací hlavních os ve směru východ - západ. Mezi významnější můžeme $\mathrm{z}$ tohoto hlediska považovat indikaci hrobu na jihozápadním úseku jižní boční zdi, v jehož sektoru je v původní dlažební desce označení † a neúplný nápis STE: PERNER 1752.

\section{ZÁVĚR}

$\mathrm{V}$ předloženém př́spěvku jsme se snažili ukázat, že účelně volený komplex nedestruktivních metod se v Čechách stal $\mathrm{v}$ průběhu posledních několika let i přes určité komplikace v jejich zavádění do praxe již nedílnou součástí komplexně pojatého archeologického výzkumu i stavebněhistorického průzkumu při řešení různých otázek spojených zejména s lokalizací hrobek, hrobů, krypt a reliktů zdiva ze starších snesených objektů $\mathrm{v}$ interiérech středověkých i novověkých církevních staveb. Ve spojení geofyzikálních metod s vizuálním průzkumem, dokumentací a prrípadně i sondáží, zabezpečuje tento postup optimální řešení požadovaných úloh, a to jak z hlediska získání velkého počtu informací, tak z hlediska časového a v neposlední řadě i ekonomického.

Z uváděných praktických příkladů výsledků dosavadní prospekce na lokalitách Praha-Hradčany, Vyšší Brod a Želiv se jeví jako optimální pro lokalizaci hrobek, hrobů a dalších struktur v interiérech kostelů metoda půdního radaru, eventuálně i mikrogravimetrie $s$ následnou prohlídkou a dokumentací kamerovým systémem.

Zjištování hrobek a hrobů v interiérech chrámů pomocí geofyzikálních metod je však dle dosavadních výsledků závislé především na litologickém charakteru nehomogenit, to znamená, jedná-li se o objekt vyzděný, nebo pouze prostý hrob, je-li nezaplněný, zavalený a podobně. Optimální pří- 
pad nastává tehdy, když je hrobka vyzděná, dutá a má větší rozměr. $\mathrm{V}$ tom prípadě jsou odrazy elektromagnetických vln nejvýraznější, respektive dochází $\mathrm{k}$ úbytku hmot a tento objekt je pak velice dobře detekovatelný. Při jeho zavalení může při výkladu docházet $\mathrm{k}$ nejednoznačné interpretaci způsobené větší plošnou kumulací kamenů, litologickými změnami v zásypu antropogenní vrstvy a relikty zdiva ze starší snesené stavby. Zde jsou potom velmi užitečné další doplňujíći informace o stavbě, jako např́klad př́ípadné polohy náhrobních kamenů, průběhy inženýrských sítí apod. Při existenci zásypu prostých hrobů obdobného litologického složení, respektive zhutnění jako $\mathrm{v}$ okolním prostředí, je jejich lokalizace vlivem nevýrazných změn fyzikálních parametrů zemin velmi problematická a mnohdy i nezjistitelná.

Zmínili jsme se zde pouze o některých nejdůležitějších praktických výsledcích a možnostech nedestruktivních metod při lokalizování různých struktur v sakrálních stavbách Čech. Závěrem můžeme konstatovat, že uváděný nedestruktivní geofyzikální a vizuální archeologický průzkum může přispívat $\mathrm{k}$ dalšímu podrobnějšímu poznávání historie významných církevních areálů na celém území České republiky.

\section{LITERATURA}

Bednár, Josef - Novotný, Antonín - Švancara, Jan (1980): Mikrogravimetrie a její uplatnění v archeologii. Sborník referátů 1. celostátní konference „Aplikace geofyzikálních metod $v$ archeologii a moderní metody terénního výzkumu a dokumentace". Petrov nad Desnou, 21-40.

Čechura, Martin (2005): Výsledky první sezóny výzkumu kostela sv. Petra a Pavla ve Svojšíně. Archeologické výzkumy v Čechách 2004. Zprávy české archeologické společnosti, 60, 30-31.

Domanský, Jiří (1983): Ověření polohy krypty v základech kostela Nejsvětější Trojice v Praze. Geofyzika a archeologie 1982, 129-131.

Dragoun, Zdeněk - Podliska, Jaroslav (2011): Výzkum v kostele sv. Nastala v Praze 1 (hledání ostatků sv. Anežky České). Zprávy České archeologické společnosti, 81, 26-27.

Hašek, Vladimír - Maštera, Lubomír - Šindelář, Jiř́i - Thomová, Zuzana (2008): Non-destructive research of the churých of birth of the virgin in Želiv by Humpolec. Študijné zvesti Archeologického ústavu Slovenskej akademie vied. 43, 5-22.

Hašek, Vladimír - Měřínský, Zdeněk (1991): Geofyzikální metody v archeologii na Moravě. Brno.

Hašek, Vladimír - Měřínský, Zdeněk (1997): Archeogeofyzikální prospekce při zjištování přičin statického narušení historických staveb na Moravě. Pravěk N

Hašek, Vladimír - Petera, Josef (2002): Geofyzikální prospekce a ověřovací sondáž podzemní Přepychách, okr. Rychnov nad Kněžnou. Přehled výzkumů Archeologického ústavu Akademie věd České republiky, 43, 317-322.

Hašek, Vladimír - Šindeláŕ, Jiří - Thomová, Zuzana - Tomešek, Jan (2008): Nedestruktivní průzkum kostela sv. Víta v Českém Krumlově. Ve službách archeologie, 1/08, 55-63.

Hašek, Vladimír - Tomešek, Jan (2006): Zpráva o archeogeofyzikální prospekci na akci Křeč - kostel sv. Jakuba Vétšího. Manuskript Geopek, spol. s r. o. Brno.

Hašek, Vladimír - Tomešek, Jan (2006a): Zpráva o archeogeofyzikální prospekci na akci Hostinné - kostel Nejsvětějuši Trojice, okr. Trutnov. Manuskript Geopek, spol. s r. o. Brno.

Hašek, Vladimír - Tomešek, Jan (2007): Zpráva o archeogeofyzikální prospekci na akci Chýnov - kostel Nejsvětější Trojice, býv. Tábor. Manuskript Geopek, spol. s r. o. Brno.
Hašek, Vladimír - Tomešek, Jan (2008): Zpráva o archeogeofyzikální prospekci na akci Litomyšl - bývalá piaristická kolej u kostela Nalezení sv. Křiže. Manuskript Geopek, spol. s r. o. Brno.

Hašek, Vladimír - Šindeláŕ, Jiř́i - Tomešek, Jan (2008): Zpráva o archeogeofyzikální prospekci na akci Obděnice - kostel Nanebevzetí P. Marie, okr. Př́bram. Manuskript Geopek, spol. s r. o. Brno.

Hašek, Vladimír - Tomešek, Jan (2009): Geofyzikální průzkum cisterciáckého kláštera ve Vyšším Brodě - I. etapa. Ve službách archeologie, 1/2009, $14-21$.

Hašek, Vladimír - Unger, Josef (2001): Geofyzikální prospekce při archeologickém výzkumu hrobek a krypt. Ve službách archeologie, II, 87-111.

Hašek, Vladimír - Unger, Josef (2010): Religions Architecture in the Czech Republic in the Light of Geophysical Prospection and Archaeological Excavation. BAR International Series 2128, 2010, Oxford.

Hašek, Vladimír - Unger, Josef - Záhora, Richard (1997): Archäologische Prospektion mit Georadar in Mähren. Beiträge zur Mittelalterarchäologie in Österreich, 13, 23-39.

Hrdlička, Ladislav - Nechvátal, Bořivoj (1983): Použití nedestruktivních metod při archeologickém výzkumu interiéru baziliky sv. Petra a Pavla na Vyšehradě. Sbornik Geofyzika a archeologie. 4. celostátní symposium. Liblice, 123-128.

Charouz, Jindřich Zdík (1995): Oživené dědictví. Premonstrátský Želiv včera a dnes. Želiv.

Janáček, J. - Louda, J. (1988): České erby. Praha.

Kalista, Zdeněk (1970): Česká barokní gotika a její ždárské ohnisko. Brno.

Křivánek, Roman (2006): Geofyzikální měření Archeologického ústavu AVČR Praha na archeologických lokalitách v roce 2005. Archeologické výzkumy v Čechách 2005. Zprávy České archeologické společnosti, 64, $7-10$.

Křivánek, Roman (2008): Geofyzikální měření Archeologického ústavu AVČR Praha na archeologických lokalitách v roce 2007. Archeologické výzkumy v Čechách 2007. Zprávy České archeologické společnosti, 71, $12-15$.

Křivánek, Roman (2009): Geofyzikální měření Archeologického ústavu AVČR Praha na archeologických lokalitách v roce 2008. Archeologické výzkumy v Čechách 2008. Zprávy České archeologické společnosti, 75 $16-19$.

Křivánek, Roman (2010): Geofyzikální měření Archeologického ústavu AVČR Praha na archeologických lokalitách v roce 2009. Archeologické výzkumy v Čechách 2009. Zprávy České archeologické společnosti, 78, 16-19.

Maříková-Kubková, Jana - Bravermanová, Milena - Kováč, Adriano et al. (2005): Předběžná zpráva o průzkumu staré královské hrobky v chóru katedrály sv. Víta na Pražském hradě. Castrum Pragense, 6, 99-119.

Poche, Emanuel et al. (1982): Umélecké památky Čech 4, T-Ž. Praha.

Vlček, Emanuel (1999-2000): Čeští králové. I, II. Praha.

Vlček, Pavel - Sommer, Petr - Foltýn, Dušan (1997): Encyklopedie českých klášterů. Praha.

Wirth, Zdeněk (1908): Barokní gotika v Čechách v XVIII a 1. polovici XIX. století. Památky archeologické, XXIII, 121-156.

\section{AUTOŘI}

Hašek, Vladimír (8. 7. 1938), geofyzik, absolvent Katedry užité geofyziky Př́rodovědecké fakulty Karlovy univerzity v Praze. Pracoval jako odborný a následně jako vědecký pracovník v Geofyzice a. s. Brno, Archeologickém ústavu AVČR Brno a nyní i jako manažer firmy Isolines, spol. s r. o. Brno. Po dobu aktivní pracovní činnosti se zabýval řešením různých úkolů $\mathrm{z}$ oblasti inženýrské geologie, hydrogeologie, ložiskové geologie a archeologické prospekce z pravěku až novověku. V roce 1991 byl jmenován doktorem geologických věd (metodologie geofyzikálního výzkumu v archeologii). Podílel se na práci řady českých i zahraničních archeologických expedic: Egypt, Německo, Rakousko, Švédsko, Polsko a Slovensko. Publikoval v ČR i zahraničí větší počet vědeckých studií a zpracoval na 320 výsledků ze svých terénních aktivit. 
Kontakt: RNDr. Vladimír Hašek, DrSc., Geopek, spol. s r. o., Ječná 29a, 62100 Brno, e-mail: hasek.vladimir@gmail.com.

Šindeláŕ, Jiří (12. 4. 1976), geodet a geoinformatik. Od roku 1994 do roku 2003 zaměstnanec geodetické kanceláře v Táboře. Zakladatel firmy Geo-cz, která se jako jediná v ČR specializuje na dokumentaci a nedestruktivní průzkum v památkové péči a archeologické památkové péči. Od roku 1993 člen speleologické skupiny ZO-2-01 a od roku 2007 odborný konzultant a spolupracovník občanského sdružení Naše historie. Od roku 2009 přednáší s Evou Talarovičovou nedestruktivní archeologii na Jihočeské univerzitě v Českých Budějovicích. Je tvůrce metodiky vizuálního a měřického průzkumu neprrístupného podzemí, vytvárí metodiku na dokumentaci historických předmětů a uměleckých děl v neviditelných spektrech světla. Spolupracuje s odborníky na dokumentaci a průzkumech významné architektury (např́klad katedrály sv. Víta, Vojtěcha a Václava na Pražském hradě) a uměleckých děl ze sbírek mnoha galerií a státních i církevních institucí.

Kontakt: Jiř́ Šindelář, Geo-cz, Noskov 21, 39145 Mladá Vožice, e-mail: geo@geo-cz.com.
Unger, Josef (11. 9. 1944, Brno), archeolog a kulturní antropolog, absolvent Katedry archeologie Filozofické fakulty Masarykovy univerzity. Pracoval jako odborný a vědecký pracovník-archeolog v Regionálním muzeu Mikulov, Archeologickém ústavu AV, Ústavu archeologické památkové péče $\mathrm{v}$ Brně. $\mathrm{V}$ oboru antropologie se habilitoval v roce 1999 (Hrad Lelekovice. Sociokulturní antropologická studie), profesorem antropologie byl jmenován v roce 2004. Přednáší Základy vědecké práce, Antropologii pravěku a středověku, Pohřební ritus, Metody antropologie. Ve výzkumné práci se zabývá především sídly a životem šlechty ve středověku, archeologií církevních objektů a antropologií pohřebního ritu. Vedl celou řadu terénních archeologických výzkumů (zaniklé vsi Topolany, Bořanovice, motte na zaniklé vsi Koválov, kostely v Mušově, Hustopečích, Tasově a na zaniklých vsích Divice, Narvice, Koválov, hrad v Lelekovicích, pohřebiště v Morkůvkách, Divákách a další). Přednášel na univerzitách v Bambergu, Banské Bystrici, Bratislavě, Göttingen, Hradci Králové, Nitře, Olomouci, Opolí, Opavě, Poznani a Wrocławi. Publikoval u nás i v zahraničí mnoho vědeckých studií.

Kontakt: Prof. PhDr. Josef Unger, CSc., Ústav antropologie, Vinařská 5, 60300 Brno, e-mail: unger@sci.muni.cz. 